\title{
UJI KUALITAS FISIK, KIMIA DAN ORGANOLEPTIK KERIPIK NANGKA HASIL MODIFIKASI MESIN VACUUM FRYING SISTEM PENDINGIN PANCURAN
}

\author{
Budi Hariono" ${ }^{\# 1}$ Abi Bakri*2, Mokh. Fatoni Kurnianto"\#3 \\ \#1,*2,\#3Jurusan Teknologi Pertanian, Politeknik Negeri Jember \\ Jl. Mastrip Kotak Pos 164, Jember \\ 1budihariono1966@gmail.com \\ 2abipolije@gmail.com \\ 3ftnpolije@gmail.com
}

\begin{abstract}
The basic principle of the vacuum frying process is the frying process is carried out at low pressure $(-760 \mathrm{~mm} \mathrm{Hg})$, so the frying temperature drops to $85^{\circ} \mathrm{C}$ (Lastriyanto, 2006). This condition causes malnutrition to be suppressed. This process is very suitable for use in fruit and vegetable commodities. The main problem of PPPE program, partners PPPE cannot fulfill demand for 1 ton of chips/month. So it is necessary to develop vacuum type refrigerant machine with capacity $30 \mathrm{~kg}$ raw material with cooling pool dimension lenght $\mathrm{x}$ wide $\mathrm{x}$ height $6 \mathrm{x} \times 3 \mathrm{~m} \times 1.5 \mathrm{~m}$ with water volume $23-25 \mathrm{~m}^{3}$. The results of the product test on this vacuum "tipe pancuran" system show significant organoleptic test can improve color, flavor and taste compared to conventional cooling method and the same relative crispness. The "tipe pancuran" method on the physical test indicates Brightness (L) is higher; the red color (redness) a lower and yellow (b) is higher than the conventional cooling method. The proximate analysis not significant. The conventional cooling method of water replacement is carried out after each one-time jackfruit chip production process with an increase in temperature of $5-6^{\circ} \mathrm{C}$ each time the process, while the replacement refrigeration shower method is carried out every 9 times of the production process with an increase of $1-2^{\circ} \mathrm{C}$ at each process.
\end{abstract}

\section{PENDAHULUAN}

Bahan baku berupa buah yang akan diproses menjadi keripik buah seperti halnya pada buah nangka, nenas, salak harus digoreng pada kondisi vakum dimana minyak mendidih pada suhu sekitar $80^{\circ} \mathrm{C}$ sehingga dihasilkan produk dengan warna yang natural serta tekstur yang renyah (Muchtadi, 2008). Apabila bahan baku digoreng pada kondisi tekanan atmosfir maka produk segera mengalami pencokelatan dan gosong, teksturnya lembek dan liat karena tidak banyak melepaskan air yang dikandungnya. Oleh karenanya sudah umum digunakan mesin vacuum frying. Umumnya mesin vacuum frying mempunyai kapasitas $6 \mathrm{~kg}$ bahan baku dengan sistem pendingin water jet dengan sistem kinerja mesin secara umum adalah sebagai berikut:
Prinsip dasar proses vacuum frying adalah proses penggorengan dilakukan pada tekanan rendah $(-760 \mathrm{~mm} \mathrm{Hg})$. Hal ini menyebabkan sehingga suhu penggorengan turun menjadi $85^{\circ} \mathrm{C}$ (Lastriyanto, 2006)., sehingga kerusakan gizi dapat ditekan. Proses ini sangat cocok digunakan pada komoditas buah dan sayur. Proses mesin penggoreng vakum konvensional terdiri atas 5 (lima) komponen utama, yakni: pompa vakum, tabung penggoreng, pengendali temperatur, kondensor, dan sumber pemanas. Fungsi bagian-bagian tersebut adalah sebagai berikut:

Deskripsi Mesin Penggoreng Vakum Sistem Pendingin Konvensional

1. Pompa vakum sistem water jet, berfungsi menghisap udara yang berada di dalam ruang penggoreng sehingga tekanan 
menjadi lebih rendah, serta untuk menghisap uap air bahan. Pompa vakum ini mempunyai spesifikasi daya listrik 1.000 Watt.

2. Tabung Penggoreng, berfungsi mengkondisikan bahan sesuai tekanan yang diinginkan yang dilengkapi keranjang buah setengah lingkaran. Tabung penggorengan mempunyai kapasitas minyak 50-60 L.

3. Kondensor, berfungsi mengembunkan uap air untuk dikeluarkan selama proses penggorengan. Kondensor menggunakan air sebagai pendingin, selanjutnya air menyerap panas penggorengan yang dikeluarkan diteruskan ke bak pendingin. Pada mesin penggoreng vakum yang konvensional menggunakan bak pendingin cukup besar dimensinya yaitu $3 \mathrm{~m} \mathrm{x} 4 \mathrm{~m} \mathrm{x}$ 1 meter, itupun airnya masih harus sering diganti karena masih mudah panas.

4. Unit Pemanas, menggunakan kompor gas LPG.

5. Unit Pengendali Operasi, berfungsi mengaktifkan alat vakum dan unit pemanas.

6. Pengaduk Penggorengan, berfungsi mengaduk buah yang berada dalam tabung penggorengan. Bagian ini perlu seal karet yang kuat untuk menjaga kevakuman tabung.

7. Mesin pengering (spinner), berfungsi meniriskan kripik.

Pada kegiatan Pengabdian ini dilakukan inovasi teknologi dengan memodifikasi system pendinginan pada penggorengan vakum dengan metoda pendingin pancuran dimaksudkan untuk mempertahankan suhu penggorengan tetap dingin sehingga menghemat penggunaan air pendingin dan meningkatkan kualitas citarasa produk keripik nangka.

\section{Permasalahan Mitra}

Permintaan keripik buah di UD Dua Dewi rata-rata per bulan sekitar 1 ton keripik. Untuk memenuhi permintaan di atas UD Dua Dewi menggunakan beberapa mesin vakum kapasitas $6 \mathrm{~kg}, 10 \mathrm{~kg}$ dan 12 $\mathrm{kg}$ bahan baku. Akan tetapi tetap belum bisa memenuhi kapasitas produksi sebesar 1 ton keripik/bulan. Oleh karenanya mulai
Januari 2017 UD Dua Dewi mengembangkan mesin dengan kapasitas $30 \mathrm{~kg}$ bahan baku sebanyak 2 buah. Khusus aplikasi mesin dengan kapasitas $30 \mathrm{~kg}$ bahan baku dilakukan modifikasi pada kolam pendingin dengan dimensi panjang $\mathrm{x}$ lebar x tinggi berturut-turut $6 \mathrm{~m} \times 3 \mathrm{~m} \times 1,5$ $\mathrm{m}$ dengan volume air $23-25 \mathrm{~m}^{3}$. Aplikasi mesin vakum kapasitas $30 \mathrm{~kg}$ dengan hasil keripik sayur dan buah berkisar 5-6 kg atau 5 kali lipat bila menggunakan mesin kapasitas kecil. Kondisi ini akan membantu mitra dalam memenuhi permintaan pasar yang cenderung meningkat.

Dengan melihat permasalahan mitra, implementasi system penggorengan vakum menggunakan metoda pendingin pancuran merupakan solusi untuk proses pengolahan keripik nangka terutama untuk penghematan penggunaan air pendingin tanpa perluasan bak pendingin dan upaya meningkatkan kualitas kerenyahan, warna, citarasa dan nutrisi produk keripik nangka. Inovasi Teknologi berdampak pada peningkatan kapasitas produksi dan kualitas produk. Upaya-upaya lain dari kegiatan pengabdian ini seperti penggunaan mesin pengemas dan perbaikan sarana produksi seperti penggantian atap ruang prosesing dengan kerangka galvalum akan sangat membantu perbaikan higien sanitasi dan kualitas produk keripik nangka.

\section{TARGET DAN LUARAN}

Target Sasaran dari kegiatan Pengabdian masyarakat IBPE ini adalah UD Dua Dewi, dari Kabupaten Jember dan UD Ananda, dari Kabupaten Lumajang yang keduanya merupakan pengusahan Keripik Nangka dan Keripik buah lainnya, yang menjadi percontohan dengan harapan pengembangan usaha melalui perbaikan ataupun inovasi teknologi dapat diterapkan pada Perusahaan Keripik Nangka ataupun Keripik buah lainnya. Dengan penerapan system penggorengan vakum menggunakan metoda pendingin pancuran, penggunaan mesin pengemas, mesin pengaduk bumbu dan perbaikan sanitasi ruang produksi maka UD Dua 
Dewi dan UD Ananda mampu meningkatkan kapasitas produksi, menghemat penggunaan air pendingin, mempercepat waktu proses, meningkatkan kualitas citarasa, fisik dan kimiawi produk. Hal ini secara tidak langsung akan meningkatkan pendapatan.

\section{Luaran kegiatan pengabdian adalah} Laporan publikasi jurnal ilmiah; Konstruksi pendinginan pancuran; penambahan alat vacuum frying dengan sistem super vakum (high vacuum), deep freezer, mesin kemasan kontinyu, perbaikan fasilitas sanitasi ruang produksi maupun ruang pengolahan bahan baku. Produk keripik nangka dengan kriteria memenuhi syarat SNI; Kualitas Fisik; Kimiawi dan citarasa memenuhi syarat dan sangat diterima oleh konsumen; hemat penggunaan Air pendingin; dan kapasitas produksi meningkat.

\section{METODE PELAKSANAAN}

a. Modifikasi Sistem Pendingin Air

Sistem pendingin masin vakum konvensional hanya mengandalkan sistem pendingin kondensor dimana uap air panas dari ruang penggoreng dilewatkan pada pipa tembaga diameter $1 / 2$ " dengan panjang 15 meter yang dibentuk rol. Pendinginan dilakukan dengan menggunakan air sistem contra flow (aliran berlawanan) dimana air pendingin masuk berasal dari kolam dengan dimensi $1,5 \mathrm{~m} \times 2 \mathrm{~m} \times 0,7 \mathrm{~m}$ atau setara dengan $2 \mathrm{~m}^{3}$ Selanjutnya air pendingin disirkulasikan di kolam pendingin. Pada sistem konvensional ini suhu air pendingin di kolam akan meningkat sebesar $5-6^{\circ} \mathrm{C} /$ proses, sehingga setiap kali proses produksi selalu direkomendasikan untuk penggantian air pendingin. Hal ini akan menambah biaya produksi karena : (1) adanya tambahan waktu untuk proses pengurasan, (2) adanya biaya listrik khususnya untuk memompa air ke kolam pendingin serta (3) adanya tida ramah lingkungan karena boros air. Modifikasi sistem pendingin metode pancuran tertera pada Gambar 3.
Sistem pendingin yang dimodifikasi pada mesin vakum kapasitas $30 \mathrm{~kg}$ adalah : (1) kolam yang digunakan mempunyai dimensi panjang $\mathrm{x}$ lebar $\mathrm{x}$ tinggi berturutturut $6 \mathrm{~m} \times 3 \mathrm{~m} \times 1,5 \mathrm{~m}$ dengan volume air 23-25 $\mathrm{m}^{3}$, (2) air pendingin yang keluar dari kondensor disemprotkan dengan cara dilewatkan ke lubang sempit (nozel) sehingga terjadi butir-butir air (droplet). Droplet ini bertujuan untuk meningkatkan luas permukaan air sehingga ketika bersentuhan dengan udara akan terjadi proses pendinginan yang maksimal. Ukuran pipa pada proses keluarnya air dari nozel adalah 2" sesuai dengan ukuran lubang pipa pada pompa yang digunakan untuk memompa air. Untuk memastikasn peningkatan suhu air pendingin selama proses produksi (2 jam), pengukuran suhu air kolam dilakukan menggunakan termokopel setiap 10 menit sekali.

b. Proses Pengolahan Keripik Nangka menggunakan Penggorengan Vakum dengan 2 metoda pendingin yaitu metoda pendingin Konvensional dan Metoda Pendingin Pancuran.

c. Analisa Sifat fisik meliputi Warna dengan Cromameter metoda Hunter Lab; Analisa Kimiawi meliputi pengujian Proksimat terdiri dari analisa Kadar Air; Karbohidrat; Protein, Lemak, dan Kadar Serat. Serta Analisa mutu Organoleptik mencakup kerenyahan, citarasa dengan analisa hedonic.

\section{HASIL DAN PEMBAHASAN}

Dari hasil pengamatan pada implementasi kegiatan pengabdian untuk proses produksi terutama dalam pengoperasian system penggorengan vakum khususnya dalam penggunaan air. Untuk metoda pendinginan konvensional penggantian air dilakukan setiap selesai satu kali proses produksi keripik nangka dengan peningkatan suhu $5-6^{\circ} \mathrm{C}$ setiap kali proses, sedangkan metoda pendinginan pancuran penggantian dilakukan setiap 9 kali proses produksi dengan peningkatan suhu $1-2{ }^{\circ} \mathrm{C}$ setiap kali proses

a. Analisa Fisik Warna 
Hasil pengamatan secara fisik diantaranya adalah Analisa Warna menggunakan Alat Chromameter. Uji warna pada peneitian ini dengan alat Hunter Lab dimana pengukuran warna dengan metode ini terdiri dari 3 parameter yaitu koordinat $\mathrm{L}^{*}$ menyatakan cahaya pantul yang menghasilkan warna akromatik putih, abuabu, dan hitam, Koordinat a* menyatakan warna kromatik merah (positif) dan hijau (negatif). Koordinat $b^{*}$ menyatakan warna kromatik kuning (positif) dan biru (negatif) (Nurmawati, 2011).

TABEL 1 RATA-RATA HASIL UJI INTENSITAS WARNA KERIPIK NANGKA

\begin{tabular}{lccc}
\hline \multirow{2}{*}{ Perlakuan } & \multicolumn{3}{c}{ Rata-rata Intensitas Warna } \\
\cline { 2 - 4 } & $\begin{array}{c}\text { Koordinat Koordinat } \\
\mathrm{L}^{*}\end{array}$ & $\begin{array}{c}\text { Koordinat } \\
\mathrm{b}^{*}\end{array}$ \\
\hline $\begin{array}{l}\text { Pendingin } \\
\text { Konvensional }\end{array}$ & 72.428 & +2.353 & +42.400 \\
$\begin{array}{l}\text { Pendingin } \\
\text { Pancuran }\end{array}$ & 74.142 & +1.233 & +45.017 \\
\hline
\end{tabular}

\section{Koordinat $\mathrm{L}^{*}$ (Lightness)}

Hasil uji warna dengan alat Chromameter metode Hunter Lab ini menghasilkan warna akromatik koordinat $\mathrm{L}$ dengan rata-rata untuk keripik nangka metoda pendingin Konvensional antara 72,428 dan metoda pendingin pancuran 74,142 , terlihat bahwa keripik nangka metoda pendingin pancuran yang dihasilkan memiliki nilai intensitas warna koordinat $\mathrm{L}^{*}$ lebih tinggi daripada keripik nangka metoda pendingin Konvensional yang mengindikasikan bahwa Keripik nangka metoda pendingin pancuran memiliki warna lebih cerah daripada pendingin Konvensional, hal ini berarti bahwa proses pendinginan pada penggorengan vakum keripik nangka metoda pendingin pancuran lebih efektif dibandingkan metoda pendingin Konvensional.

\section{Koordinat a* (Redness)}

Pada hasil pengujian ini didapatkan nilai intensitas warna koordinat $a^{*}$ (redness) atau tingkat warna merah memiliki rata-rata untuk keripik nangka metoda pendingin Konvensional yaitu + 2.353 dan metoda pendingin pancuran yaitu + 1.233, hal ini memperlihatkan bahwa pada keripik nangka metoda pendingin Konvensional memiliki warna lebih merah dibandingkan metoda pendingin pancuran, kemungkinan karena metoda pendingin Konvensional relatif kurang efektif dalam mempertahankan suhu penggorengan vakum sehingga masih dapat menimbulkan terjadinya reaksi Browning non enzimatis seperti Reaksi

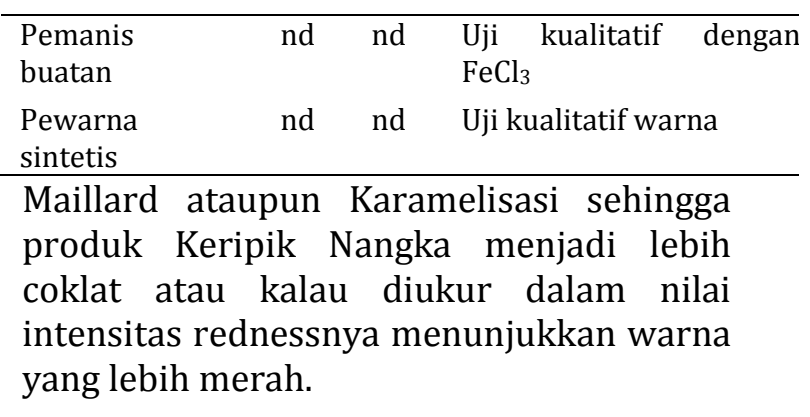

\section{Koordinat $\mathbf{b}^{*}$ (Yellowness)}

Pada hasil pengujian ini didapatkan nilai koordinat $\mathrm{b}^{*}$ (Yellowness) atau tingkat warna kuning pada keripik nangka metoda pendingin Konvensional memiliki rata-rata yaitu +42.400 dan metoda pendingin pancuran memiliki nilai rata-rata yaitu + 45.017. Dari hasil tersebut diketahui bahwa keripik nangka metoda pendingin pancuran memiliki warna yang cenderung lebih kuning daripada metoda pendingin Konvensional, hal ini berkaitan proses pendinginan dengan metoda pendingin pancuran lebih efektif dari metoda pendingin Konvensional sehingga bisa mempertahankan suhu penggorengan vakum tetap rendah dan dapat lebih mempertahankan warna kuning yang disebabkan adanya kandungan karoten (pigmen kuning).

\section{b. Analisa Proksimat (Kimiawi)}

Hasil analisa proksimat kandungan kimiawi Keripik Nangka sebagai berikut 


\begin{tabular}{|c|c|c|c|c|}
\hline $\begin{array}{l}\text { Kompon } \\
\text { en } \\
\text { Kimiawi }\end{array}$ & Satuan & $\begin{array}{c}\text { Keripik } \\
\text { Nangka } \\
\text { Pendingin } \\
\text { Konvensional }\end{array}$ & $\begin{array}{c}\text { Keripik } \\
\text { Nangka } \\
\text { Pendingin } \\
\text { Pancuran }\end{array}$ & $\begin{array}{l}\text { Metode } \\
\text { Analisa }\end{array}$ \\
\hline $\begin{array}{c}\text { Protein } \\
\text { Total }\end{array}$ & $\%$ & 3,569 & 4,225 & $\begin{array}{l}\text { Kjeldahl, } \\
\text { Trimetry }\end{array}$ \\
\hline Lemak & $\%$ & 11 & 21,250 & $\begin{array}{l}\text { Ekstraksi } \\
\text { dengan } \\
\text { soxlet }\end{array}$ \\
\hline Serat & $\%$ & 0,275 & 0,450 & $\begin{array}{l}\text { Gravimetr } \\
\text { i }\end{array}$ \\
\hline Kadar air & $\%$ & 4,693 & 2,871 & $\begin{array}{l}\text { Oven } \\
105^{\circ} \mathrm{C}\end{array}$ \\
\hline $\begin{array}{l}\text { Kadar } \\
\text { abu }\end{array}$ & $\%$ & 3,063 & 2,881 & $\begin{array}{l}\text { Pengabua } \\
\text { n kering }\end{array}$ \\
\hline $\begin{array}{c}\text { Karbohid } \\
\text { rat total }\end{array}$ & $\%$ & 24,950 & 23,405 & $\begin{array}{l}\text { Luff } \\
\text { Schrool }\end{array}$ \\
\hline
\end{tabular}

Hasil Analisa Proksimat di Laboratorium Biscience, Polije (2017)

Dari hasil analisa Proksimat Keripik Nangka menunjukkan bahwa kedua metoda pengolahan keripik Nangka Sistem Pendingin Konvensional dan Pendingin Pancuran relatif tidak berbeda nyata, hal ini juga sesuai dengan Standar Nasional Indonesia (SNI) untuk produk Keripik Nangka.

c. Analisa Organoleptik dengan Uji Hedonik Hasil analisa organoleptik keripik Nangka dengan uji hedonic meliputi kerenyahan; aroma dan rasa seperti tertera pada Gambar 1.

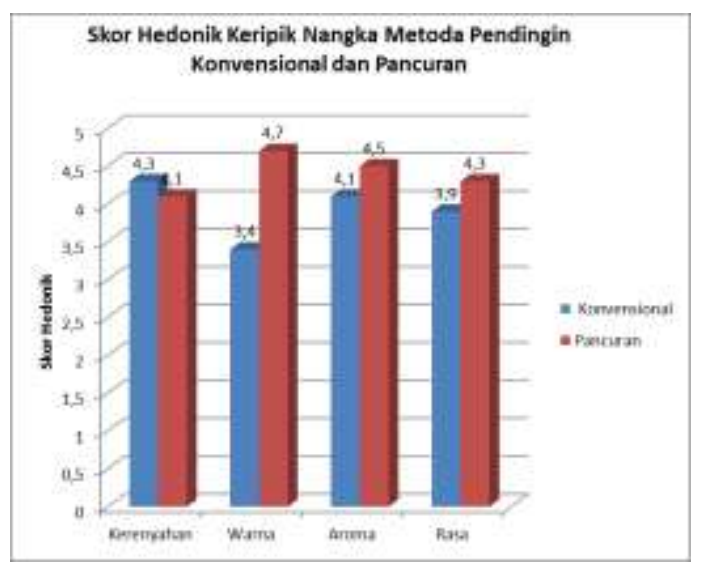

Gambar 1. Analisa Organoleptik dengan Uji Hedonik
Dari Grafik tersebut terlihat bahwa system penggorengan Vakum pada keripik nangka dengan metoda pendingin pancuran secara signifikan dapat meningkatkan warna, aroma dan rasa dibandingkan metoda pendingin konvensional sedangkan kerenyahan relative sama antar keduanya.

\section{KESIMPULAN}

Sistem penggorengan Vakum pada keripik nangka dengan metoda pendingin pancuran dengan uji organoleptik secara signifikan dapat meningkatkan warna, aroma dan rasa dibandingkan metoda pendingin konvensional sedangkan kerenyahan relative sama antar keduanya, sedangkan metoda pendingin pancuran dengan uji fisik menunjukkan Kecerahan (L) lebih tinggi; warna merah (rednes) atau a lebih rendah dan dan warna kuning (b) lebih tinggi dibandingkan metoda pendingin konvensional, selanjutnya untuk analisa proksimat antara kedua metoda pendingin relative sama.

Selanjutnya untuk perkembangan dari hasil implementasi pengabdian untuk proses produksi terutama dalam pengoperasian system penggorengan vakum khususnya dalam penggunaan air. Untuk metoda pendinginan konvensional penggantian air dilakukan setiap selesai satu kali proses produksi keripik nangka dengan peningkatan suhu $5-6^{\circ} \mathrm{C}$ setiap kali proses, sedangkan metoda pendinginan pancuran penggantian dilakukan setiap 9 kali proses produksi dengan peningkatan suhu $1-2{ }^{\circ} \mathrm{C}$ setiap kali proses

\section{UCAPAN TERIMAKASIH}

Pengabdian Masyarakat dilaksanakan dengan dana dari Direktorat Riset dan Pengabdian Kepada Masyarakat Kementerian Riset, Teknologi dan Pendidikan Tinggi untuk Program IbPE dengan nomor kontrak 034/SP2H/LT/DRPM/IV/2017. 


\section{DAFTAR PUSTAKA}

Arannugroho, R.A., 2011. Studi Kelayakan Pendirian Industri Pengolahan Keripik Nangka di Kabupaten Semarang.

Hariyadi P, Eko H, Rizki T, D Tresnakusumah, dan Nana S. 2000. Penuntun Praktikum Satuan Operasi Industri Pangan. Teknologi Pangan dan Gizi. Institute Pertanian Bogor, Bogor.

Husein U. 2003. Studi Kelayakan Bisnis : Teknik Menganalisis Kelayakan Rencana Bisnis secara Komprehensif. Gramedia Pustaka Utama, Jakarta.

Lastriyanto, A., 2006. Mesin Penggorengan Vakum (Vacuum Fryer). Malang: Lastrindo Engineering .
Muchtadi TR. 2008. Teknologi Proses Pengolahan Pangan. 3rd ed. Bogor: Institut Pertanian Bogor.

Rukmana R. 2008. Budi Daya Nangka. Kanisius, Yogyakarta.

Shing k, Y. 2003. Vaccum Frying. http//www.google. com. [12 Desember 2015].

Taqi FM. Skripsi. Karakteristik Proses Pengeringan dan Penggorengan Hampa Buah Nangka (Artocarpus heterophyllus. Imk). Fakultas Teknologi Pertanian.Institut Pertanian Bogor,Bogor. 